\title{
The investigation of aeration optimization in a pilot-scale anoxic- anaerobic oxidation ditch for nutrient removal from wastewater
}

\author{
Li-Chao Nengzi ${ }^{1, a}$, Ying Jiang ${ }^{2, b}$, Xiao-Fang Li, ${ }^{3, c}$, Wu-Jia Hailai ${ }^{4, d}$, Jin-Hua \\ $\mathrm{Ma}^{5, \mathrm{e}}$, Rui $\mathrm{CaO}^{6, f}$
}

${ }^{1}$ College of Resources and Environment,Xichang University,Xichang,People's Republic of China.

${ }^{1}$ Academy of Economics and Environmental Sciences, Xichang University, Xichang, People's Republic of China.

${ }^{2,3,4,5,6}$ College of Resources and Environment,Xichang University,Xichang,People's Republic of China.

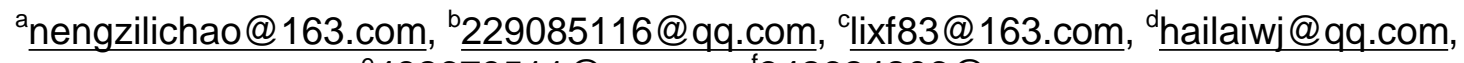

492679511@qq.com, '342624206@qq.com

Keyword. Anoxic-anaerobic oxidation ditch, Biological nitrogen and phosphorus removal, Aeration optimization, Pilot-scale

Abstract. The performance of nitrogen and phosphorus removal in a pilot-scale anoxic-anaerobic oxidation ditch (OD) process was investigated. In order to achieve a high removal efficiency of nitrogen and phosphorus, the aeration was optimized and an anoxic zone was formed in the front of OD reactor, thus the operation condition was changed to anoxic/anaerobic/anoxic/aerobic. Denitrification and DPR was occurred in the formed anoxic zone, while SND was occurred in the back of the OD reactor, and energy costs were reduced as DO in the OD reactor was relatively low. The optimal parameters of DO, RSR, SRT and MLSS were 0.55 0.65 mg/L, $58 \%, 12$ days and $2416 \sim 2636 \mathrm{mg} / \mathrm{L}$, respectively. The concentration of COD, $\mathrm{TN}, \mathrm{NH}_{4}{ }^{+}-\mathrm{N}$ and $\mathrm{TP}$ in effluent was 18.2 $\mathrm{mg} / \mathrm{L}, 13.8 \mathrm{mg} / \mathrm{L}, 3.6 \mathrm{mg} / \mathrm{L}$ and $0.42 \mathrm{mg} / \mathrm{L}$, respectively, and the average removal rate of them was $94.1 \%, 70.6 \%, 91.8 \%$ and $88.0 \%$, respectively.

\section{Introduction}

With the development of biological wastewater treatment technologies, the pollution caused by organic substance was controlled, but how to simultaneously remove nitrogen and phosphorus, which were the key nutrients causing eutrophication [1,2], became the new problem for researchers. In order to solve the problem, many biological nutrient removal (BNR) systems were developed[3,4], such as the University of Cape Town (UCT) system, the Bardenpho process, the Anaerobic-Anoxic-Oxic $\left(\mathrm{A}^{2} \mathrm{O}\right)$ system, the Oxidation Ditch (OD) system [5,6]. But few systems had a high removal efficiency of both nitrogen and phosphorus, especially for municipal wastewater because of the absence of organic substance. And in order to relieve and eliminate the negative impact of wastewater on water systems, the government of China promulgated a more strict effluent standard, which was 《contamination discharge standards of town wastewater treatment plant (WWTP) 》(GB 18918-2002) and the concentration of total nitrogen (TN) and total phosphorus (TP) was $15 \mathrm{mg} / \mathrm{L}$ and $0.5 \mathrm{mg} / \mathrm{L}$, respectively, in the first level A criteria of (GB18918 -2002), so most of the systems needed to upgrade [7].

In recent years, simultaneous nitrification and denitrification (SND) [8 10] and denitrifying phosphorus removal (DPR) [5,11,12] have become the research focuses. The SND has some advantages in the wastewater biological nitrogen removal field, such as high nitrogen removing efficiency, alkalinity production and low dissolved oxygen (DO) consumption [13,14]. And the DPR has the advantages, such as carbon sources that can be used for denitrification and phosphorus uptake, simultaneous removal of nitrogen and phosphorus, less sludge production and aeration energy saving $[5,13,15]$.

OD process is a widely used BNR process, because long hydraulic retention time (HRT) and complete mixing minimize the impact of a shock load, produces less sludge and energy efficient operations result in reduced energy costs $[16,17]$. Anoxic-anaerobic OD process is combined $\mathrm{A}^{2} \mathrm{O}$ 
process with OD process, and can removal nitrogen and phosphorus simultaneously. But when anoxic-anaerobic OD process was used to treat municipal wastewater in China, the removal efficiency of TN and TP was relatively low, the reason was as followed: the concentration of chemical oxygen demand (COD) in the municipal wastewater was relatively low, while the nitrogen and phosphorus were relatively high. Therefore in anoxic-anaerobic OD process, the COD concentration was less than $100 \mathrm{mg} / \mathrm{L}$ in the effluent of anaerobic zone, the ammonia nitrogen was nitrified quickly in the front of the OD reactor, and the aeration in the back of the OD was high and useless, so denitrification could not be occurred in this condition, and the removal rate of TN was low. In addition, the high concentration of DO and nitrate nitrogen in the return sludge affected phosphorus releasing, and the phosphorus uptake.

If SND and DPR were occurred in the anoxic-anaerobic OD process, the removal rate of TN and TP may be obviously increased. In order to create a suitable condition for SND and DPR, the aeration in the OD reactor needed to be optimized. The optimal strategy of aeration was that the aeration in the front of OD reactor was reduced to little, and an anoxic zone was formed in that place, thus denitrification and DPR could be occurred in the formed anoxic zone, and SND could be occurred in that place, where the dissolved oxygen (DO) was relatively low [10]. The aim of this study was to investigate the performance of nitrogen and phosphorus removal in a pilot-scale anoxic-anaerobic OD process in such strategy.

\section{Materials and methods}

pilot-scale plant.The experiment had been carried out in a pilot-scale anaerobic-anoxic OD process. Configuration process was shown in Fig.1, this process consisted of a water tank (200 L), an anoxic zone (29 L, the former anoxic zone), an anaerobic zone $(29 \mathrm{~L})$, an OD reactor $(216 \mathrm{~L})$ and a secondary clarifier $(53 \mathrm{~L})$. The former anoxic and anaerobic zones were made of Plexiglas, and the others were made of stainless steel. The influent rate was $15 \mathrm{~L} / \mathrm{h}$, which given a HRT of $1.9 \mathrm{~h}, 1.9 \mathrm{~h}$ and $14.4 \mathrm{~h}$, respectively, in the three zones, and $10 \%$ of total influent and all return sludge were pumped to the anoxic zone, while the remaining $90 \%$ of influent were pumped to anaerobic zone. Mixers were equipped in the anoxic and anaerobic zones, which made the sludge suspend, and three mixers were set up in the OD reactor, in order to make the mixed liquids flow in the OD reactor. DO was controlled artificially, oxidation-reduction potential (ORP) and $\mathrm{pH}$ were monitored but were not controlled. The quantity of aeration was little in the 1, 2 and 3 galleries of the OD reactor, which made the sludge suspend.

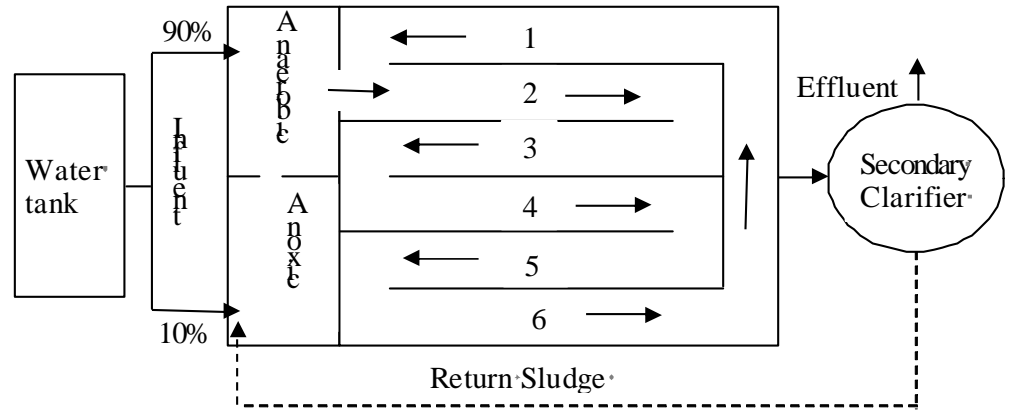

Fig.1 Schematic diagram of the oxidation ditch system

\section{Wastewater and sludge.}

Tab. 1 Major characteristics of the influent

\begin{tabular}{ccccccc}
\hline \multicolumn{2}{c}{ Parameter } & $\mathrm{pH}$ & $\mathrm{COD}(\mathrm{mg} / \mathrm{l})$ & $\mathrm{NH}_{4}{ }^{+} \mathrm{N}(\mathrm{mg} / \mathrm{l})$ & $\mathrm{TN}(\mathrm{mg} / \mathrm{l})$ & $\mathrm{TP}(\mathrm{mg} / \mathrm{l})$ \\
\hline \multirow{2}{*}{ Influent } & Range & $6.87 \sim 7.39$ & $115 \sim 449$ & $27.4 \sim 60.8$ & $32.5 \sim 69.8$ & $2.16 \sim 5.37$ \\
& Average & 7.15 & 299 & 45.6 & 48.2 & 3.69 \\
\hline
\end{tabular}

Wastewater was obtained from residential subdistricts in Xinxiang China. The concentration of TN in the raw wastewater was very high, but COD and TP were comparatively low, so the wastewater was diluted by tap water, and then sugar and $\mathrm{KH}_{2} \mathrm{P}_{4} \mathrm{O}_{3}$ were added to supplement COD and TP in 
this experiment. Major characteristics of the influent were shown in table 1. The sludge was taken from the $\mathrm{A}^{2} \mathrm{O}$ process of luotuowan wastewater treatment plant (WWTP) in Xinxiang China.

Pilot-scale plant set-up and operation.Biomasses were enriched in the pilot-scale anoxicanaerobic OD process. At the beginning the anoxic-anaerobic OD process was fed with real municipal wastewater, and foams appeared in the OD reactor about ten days later, the reasons were as followed: (a) The temperature was very low and was only about $10{ }^{\circ} \mathrm{C}$; (b) the concentrations of $\mathrm{COD}$ and $\mathrm{NH}_{4}{ }^{+}-\mathrm{N}$ were too high, and fluctuated drastically and were about 500 2000 mg/L and $120 \sim 250 \mathrm{mg} / \mathrm{L}$, respectively. Then the temperature was controlled at $24 \sim 26{ }^{\circ} \mathrm{C}$ and the concentration of COD, TN, TP in influent was controlled as table 1. A few days later foams disappeared.

The purpose of phase I (phase I data not shown) was to improve the removal rate of COD and ammonia nitrogen. The concentration of DO in the OD reactor was $1.5 \sim 2.0 \mathrm{mg} / \mathrm{L}$, and the return sludge rate (RSR) was $100 \% .25$ days later, the concentration of COD and ammonia in effluent was reduced to less then $30 \mathrm{mg} / \mathrm{L}$ and $10 \mathrm{mg} / \mathrm{L}$, respectively. The purpose of phase I was reached.

The purpose of phase II was to enhance the removal rate of TN and TP. In order to get the goal, the DO was reduced gradually; finally, the DO was reduced to about $0.1 \sim 0.2 \mathrm{mg} / \mathrm{L}$ in 2 and 3 galleries, and a anoxic zone (the latter anoxic zone) was formed in there where denitrification was occurred, while the DO was reduced to relatively low in the 4, 5 and 6 galleries where SND was occurred. Simultaneously the RSR was decreased gradually too, and when the RSR was decreased to $58 \%$, the nitrate nitrogen in the return sludge was used up in the former anoxic zone, and phosphorus released well in the anaerobic zone. Phase III was steady phase. The DO, RSR, solids retention time (SRT) and mixed liquor suspended solids (MLSS) were 0.55 0.65 mg/L, $58 \%, 12$ days and 2416 2636 mg/L, respectively.

Analysis. The analyses of $\mathrm{TN}, \mathrm{NH}_{4}{ }^{-}-\mathrm{N}, \mathrm{NO}_{3}{ }^{-} \mathrm{N}, \mathrm{NO}_{2}{ }^{-} \mathrm{N}, \mathrm{TP}$ and MLSS were performed as described in the Standard Methods of APHA (APHA, 1995). COD was measured using CR3200photolab sb (WTW, Germany), DO, pH, ORP, and temperature were measured continuously using online probes (Multi340i, WTW, Germany).

\section{Results and discussions}
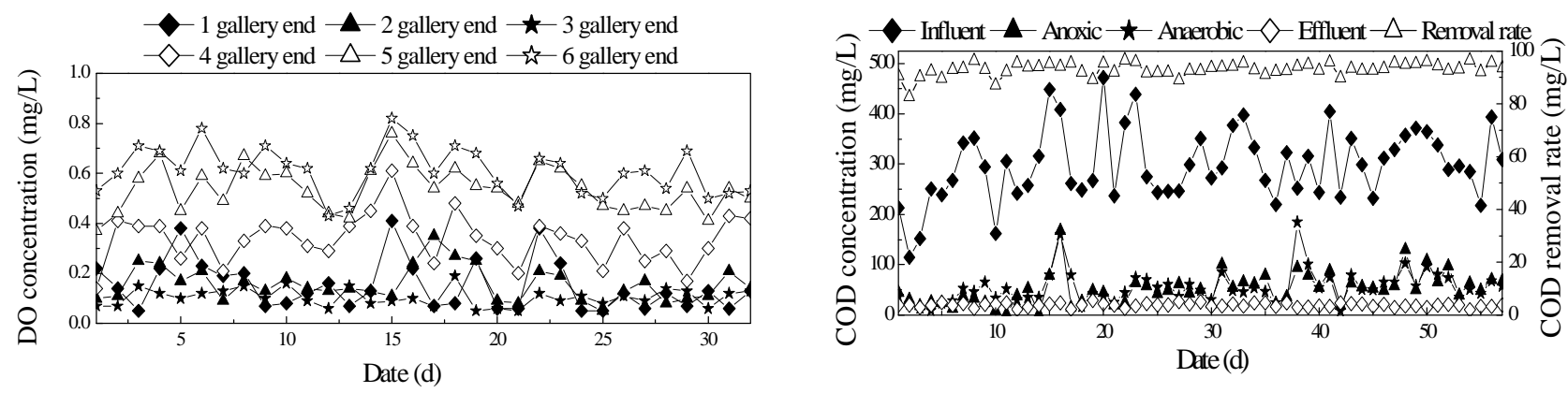

Fig.2 varieties of DO concentration in OD system

Fig.3 Effect of anoxic-anaerobic OD on COD removal

DO concentration in the OD system.Fig 2 presents the varieties of DO concentration in OD reactor. DO was measured in each gallery end, where was the effluent of each gallery in this experiment. The DO was obviously fluctuated in the 1 gallery end and was about $0.2 \mathrm{mg} / \mathrm{L}$, which was influenced by return mixture. The DO was low in 2 and 3 galleries end, only about $0.15 \mathrm{mg} / \mathrm{L}$ and $0.1 \mathrm{mg} / \mathrm{L}$, respectively, so a anoxic zone (the latter anoxic zone) was formed in this place where denitrification and DPR were occurred. The DO was approximately $0.2 \sim 0.6 \mathrm{mg} / \mathrm{L}$ in 4,5 and 6 galleries, where was the aerobic zone and the SND was occurred. The DO in the OD reactor was relatively low and energy cost was reduced.

Organic substance removal.Fig. 3 presents the varieties concentration of COD and its removal efficiency of anoxic-anaerobic OD process during the whole operation period. The concentration of COD in influent was relatively low in the first 10 days, most of the COD was lower than $250 \mathrm{mg} / \mathrm{L}$, and the COD was fluctuated between $200 \sim 450 \mathrm{mg} / \mathrm{L}$ in the later days. The COD was very low in 
the former anoxic zone, only about $50 \mathrm{mg} / \mathrm{L}$, because only $10 \%$ of the influent was pumped to the former anoxic zone, while the COD was a little higher in the anaerobic zone, therefore most of the COD was removed in these two zones. The reasons for that phenomenon was as followed: (a) the influent was diluted by the return sludge; (b) part of the organic substance was adsorbed by biomass; (c) most of the organic substance was assimilated by polyphosphate accumulating organisms (PAOs) and glycogen accumulating organisms (GAOs).

The concentration of COD in effluent was low and was only about $20 \mathrm{mg} / \mathrm{L}$. Most of the COD removal rate was higher than $90 \%$ and the average removal rate of COD was $93 \%$, thus the anoxic-anaerobic OD process had a high removal efficiency of organic substance.

Nitrogen removal.The varieties concentration of $\mathrm{TN}$ and its removal efficiency of anoxicanaerobic OD system during the whole operation period were shown in Fig 4 (a). The concentration of TN in influent was fluctuated between $30 \sim 70 \mathrm{mg} / \mathrm{L}$, and the average concentration was 48.2 $\mathrm{mg} / \mathrm{L}$. The TN was diluted, adsorbed and assimilated in the former anoxic and anaerobic zones, it was about $30 \mathrm{mg} / \mathrm{L}$ in the both zones, and was a little higher in the anaerobic zone than in the former anoxic zone. At the beginning of the phase II, the concentration of TN in effluent was above $20 \mathrm{mg} / \mathrm{L}$. In order to improve the removal efficiency of TN, the DO was decreased gradually in the OD reactor, then an anoxic place was formed in the 2 and 3 galleries in the OD reactor, and the DO was $0.55 \sim 0.65 \mathrm{mg} / \mathrm{L}$ in the 6 gallery. The $\mathrm{NH}_{4}{ }^{+}-\mathrm{N}$ was nitrified in the 4,5 and 6 galleries, and denitrifying bacteria which used the organic substance from the effluent of anaerobic zone denitrified the nitrate and nitrite to nitrogen gas $\left(\mathrm{N}_{2}\right)$ in the 2 and 3 galleries[18 20]. The DO was relatively low in the back of the OD reactor, so SND was occurred in this place.

The concentration of TN in effluent was decreased gradually in the phase II and reduced to lower than $15 \mathrm{mg} / \mathrm{L}$ in the $21^{\text {st }}$ day, after that day, the TN was lower than $15 \mathrm{mg} / \mathrm{L}$ except the $39^{\text {th }}$ and $40^{\text {th }}$ days, and the concentration of TN in OD effluent was a little higher than in the secondary clarifier, because nitrification and denitrification were occurred in the secondary clarifier.
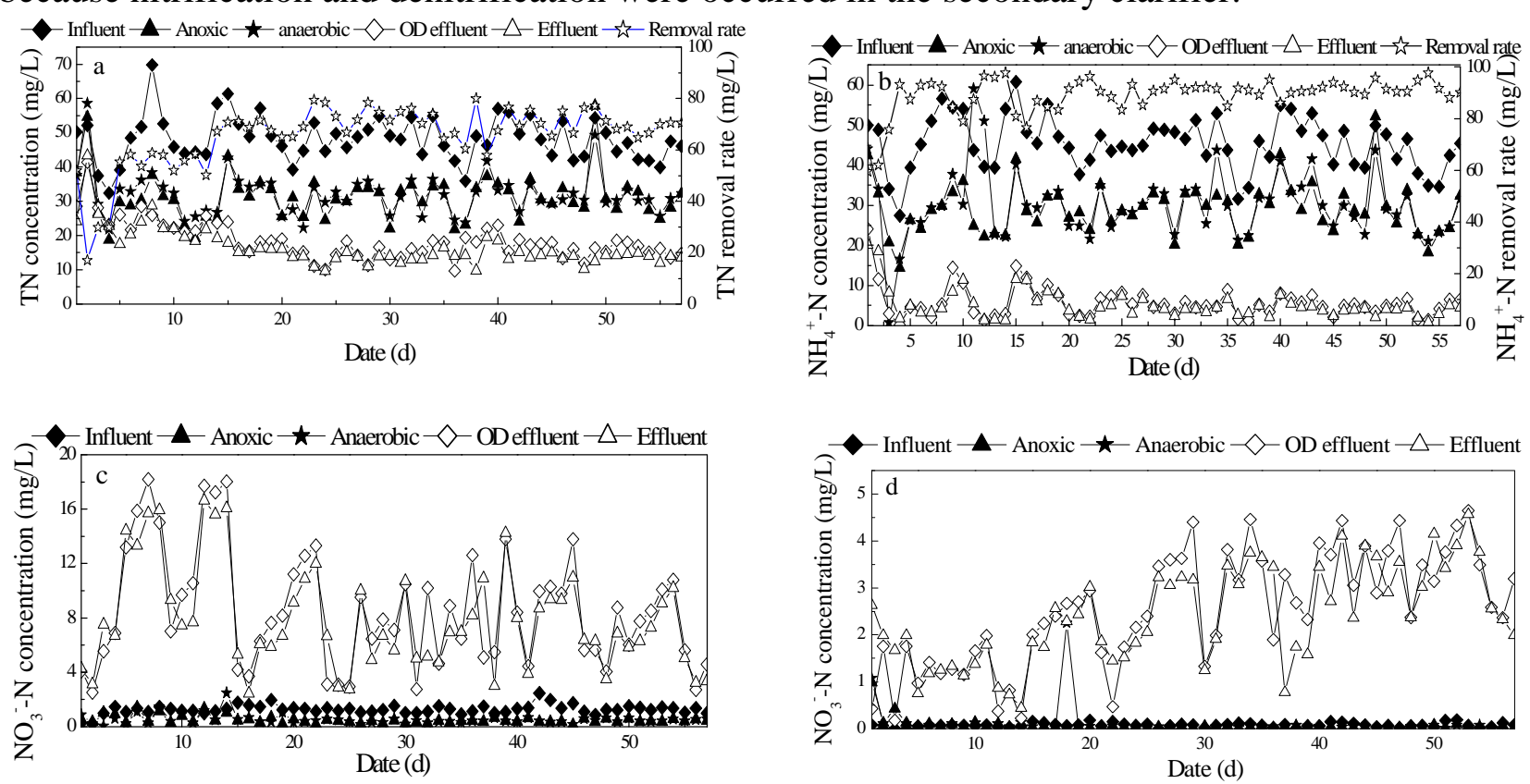

Fig.4 Effect of anoxic-anaerobic OD process on $\mathrm{TN}(\mathrm{a}), \mathrm{NH}_{4}{ }^{+}-\mathrm{N}(\mathrm{b}), \mathrm{NO}_{3}{ }^{-} \mathrm{-N}(\mathrm{c})$ and $\mathrm{NO}_{2}{ }^{-}-\mathrm{N}(\mathrm{d})$ removal, respectively

The varieties concentration of $\mathrm{NH}_{4}{ }^{+}-\mathrm{N}, \mathrm{NO}_{3}{ }^{-}-\mathrm{N}$ and $\mathrm{NO}_{2}{ }^{-}-\mathrm{N}$ and their removal efficiency of anoxicanaerobic OD system during the whole operation period were shown in Fig 4 (b), Fig 4 (c) and Fig 4 (d), respectively. The concentration of $\mathrm{NH}_{4}{ }^{+}-\mathrm{N}$ in influent was fluctuated drastically in the first 15

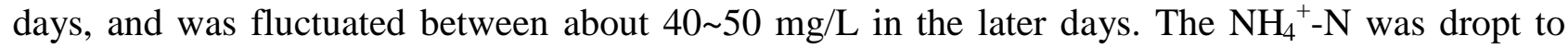
approximately $30 \mathrm{mg} / \mathrm{L}$ in the former anoxic and anaerobic zones, and most of the $\mathrm{NH}_{4}{ }^{+}-\mathrm{N}$ was removed in OD reactor, which was nitrified to nitrate and nitrite by nitrifying bacteria. The concentration of $\mathrm{NH}_{4}{ }^{+}-\mathrm{N}$ in OD effluent was less than $5 \mathrm{mg} / \mathrm{L}$ since the $20^{\text {th }}$ day, and $\mathrm{NH}_{4}{ }^{+}-\mathrm{N}$ in the 
secondary clarifier effluent was lower than in the OD effluent, because nitrification happened in the secondary clarifier. The removal rate of $\mathrm{NH}_{4}{ }^{+}-\mathrm{N}$ was more than $90 \%$ since the $20^{\text {th }}$ day.

The concentration of $\mathrm{NO}_{3}{ }^{-} \mathrm{N}$ in influent was only about $1 \mathrm{mg} / \mathrm{L}$, and $\mathrm{NO}_{3}{ }^{-} \mathrm{N}$ in the former anoxic and anaerobic zones was both about $0.5 \mathrm{mg} / \mathrm{L}$. The $\mathrm{NO}_{3}^{-}-\mathrm{N}$ was fluctuated drastically in OD effluent, and it was relatively high in the $6^{\text {th }}, 7^{\text {th }}, 8^{\text {th }}, 12^{\text {th }}, 13^{\text {th }}$ and $14^{\text {th }}$ days. The concentration of $\mathrm{NO}_{3}{ }^{-}-\mathrm{N}$ was affected by nitrifying rate and denitrifying rate, and when the nitrifying rate was higher than denitrifying rate, the $\mathrm{NO}_{3}^{-}-\mathrm{N}$ was accumulated.

The concentration of $\mathrm{NO}_{2}^{-}-\mathrm{N}$ was very low in influent, the former anoxic and anaerobic zones, but was relatively high in the OD effluent, and $\mathrm{NO}_{2}{ }^{-}-\mathrm{N}$ was about $3 \mathrm{mg} / \mathrm{L}$ since the $26^{\text {th }}$ day. Some researchers believed that $\mathrm{NO}_{2}^{-}-\mathrm{N}$ was harmful to other bacteria, when it was above certain concentration, but the inhabitation to other bacteria was not found in this experiment.

Phosphorus removal.The varieties concentration of TP and its removal efficiency of anoxicanaerobic OD system during the whole operation period were shown in Fig 5. The concentration of TP in influent was low in the first 6 days and was about $3 \sim 5 \mathrm{mg} / \mathrm{L}$ since the $7^{\text {th }}$ day. The TP in the former anoxic and anaerobic zones was lower than in influent in the $2^{\text {nd }}$ and $3^{\text {rd }}$ days, while it was about two times higher than in influent from the $4^{\text {th }}$ day to $28^{\text {th }}$ day except the $13^{\text {th }}$ day, and was about three times since the $29^{\text {th }}$ day except the $45^{\text {th }}$ day. The concentration of TP was very low in the former anoxic and anaerobic zones in the $13^{\text {th }}$ and the $45^{\text {th }}$ days, the speculated reasons may be that MLSS was low in the return sludge, because there was no mechanical sludge scraper in the secondary clarifier, and sludge sedimentation needed mix artificially, or the return sludge pipe was clogged; both of the reasons induced low MLSS in the former anoxic and anaerobic zones. The performance of phosphorus releasing was become well gradually as DO was gradually decreased.

Under anaerobic condition, facultative bacteria transformed the organic substance to available biodegradable organic carbon, then PAOs preferential transported the production across their cell membranes, hence produced polyhydroxybutyrate (PHB) and released orthophosphate, and the energy used in this reaction was released from the hydrolysis of intracellular polyphosphate and glycogen [21]. Under the aerobic or anoxic condition, PAOs used the energy released from degradation of PHB to absorb the orthophosphate more than needed for growth from the mixture, transformed to intracellular polyphosphate, and formed phosphorus-rich sludge. The more the phosphorus was released in the anaerobic phase, the more it was up-taken in the aerobic phase, finally, phosphorus was discharged as surplus sludge [22].

The concentration of TP in the OD effluent was above $1.5 \mathrm{mg} / \mathrm{L}$ in the first two days, in the next 3 days it was about $0.5 \mathrm{mg} / \mathrm{L}$, but TP was increased to about $1 \mathrm{mg} / \mathrm{L}$ in the following days, until the $40^{\text {th }}$ day TP was decreased to less than $0.5 \mathrm{mg} / \mathrm{L}$ again. The removal rate of TP was increased to above $85 \%$ since the $40^{\text {th }}$ day, and the average removal rate of TP was $88.0 \%$.

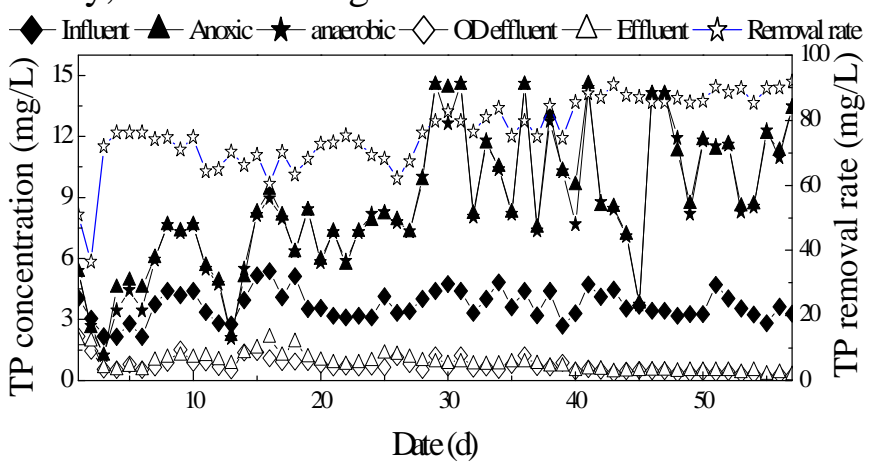

Fig.5 Effect of anoxic-anaerobic OD on TP removal

\section{Conclusions}

In order to improve the removal rate of TN and TP in the anoxic-anaerobic OD system, the aeration was optimized and an anoxic place was formed in the 2 and 3 galleries in the OD reactor. When the anoxic place was formed, denitrification and DPR could happen in this place, and SND happen in the aerobic place of the OD reactor. 
In the steady phase, nitrite was accumulated in the OD reactor, and the concentration of nitrite was about $3 \mathrm{mg} / \mathrm{L}$, but it did not affect the removal efficiency of organic substance, nitrogen and phosphorus; and the DO in the OD reactor was relatively low and energy costs was reduced. Optimal parameters of the DO, RSR, SRT and MLSS were 0.55 0.65 mg/L, $58 \%, 12$ days and $2416 \sim 2636 \mathrm{mg} / \mathrm{L}$. The concentration of COD, TN, $\mathrm{NH}_{4}{ }^{+}-\mathrm{N}$ and $\mathrm{TP}$ in effluent was $18.2 \mathrm{mg} / \mathrm{L}, 13.8$ $\mathrm{mg} / \mathrm{L}, 3.6 \mathrm{mg} / \mathrm{L}$ and $0.42 \mathrm{mg} / \mathrm{L}$, respectively. The average removal rate of them were $94.1 \%$, $70.6 \%, 91.8 \%$ and $88.0 \%$, respectively.

\section{Acknowledgements}

This work was financially supported by the National Natural Science Foundation of China (NO. 21107023), and Fund Project of Sichuan Provincial Department of Education (NO. 16ZB0258).

\section{References}

[1] Xiong Zheng, Juan Tong, Hongjing Li,Yinguang Chen. The investigation of effect of organic carbon sources addition in anaerobic-aerobic (low dissolved oxygen) sequencing batch reactor for nutrients removal from wastewaters. Bioresource Technology. 100(2009)2515-2520.

[2]Hongjing Li, Yinguang Chen, Guowei $\mathrm{Gu}$. The effect of propionic to acetic acid ratio on anaerobic-aerobic(low dissolved oxygen) biological phosphorus and nitrogen removal. Bioresource Technology. 99(2008)4400-4407

[3]Obaja D, Mace S, Mata Alvarez J. Biological nutrient removal by a sequencing batch reactor using an internal organic carbon source in digested piggery wastewater. Bioresour Technol. 96(2005)7-14.

[4]Tanwar P, Nandy T, Khan R, Biswas R. Intermittent cyclic process for enhanced biological nutrient removal treating combined chemical laboratory wastewater. Bioresour Technol. 98(2007)2473-2478.

[5]Yongzhen Peng, Xiaolian Wang, Baikun Li. Anoxic biological phosphorus uptake and the effect of excessive aeration on biological phosphorus removal in the $\mathrm{A}^{2} \mathrm{O}$ process. Desalination. 189(2006)155-164.

[6]Zeng R J, Lemaire R, Yuan Z, Keller J. Simultaneous nitrification, denitrification, and phosphorus removal in a lab-scale sequencing batch reactor. Biotech Bioeng, 84(2003)170-178.

[7]Eun Tae Lim, Gwi Taek Jeong, Sung Hun Bhang, Seok Hwan Park, Don-Hee Park. Evaluation of pilot-scale modified $\mathrm{A}^{2} \mathrm{O}$ processes for the removal of nitrogen compounds from sewage. Bioresource Technology. 100(2009)6149-6154

[8]E.V. Münch, P. Lant, J. Keller. Simultaneous nitrification and denitrification in bench-scale sequencing batch reactors.Water Res. 30(1996)277-284.

[9]Holman J B, Wareham D G.. COD, ammonia and dissolved oxygen time profiles in the simultaneous nitrification/denitrification process. Biochemical Engineering Journal. 22(2005) 125133.

[10]Meyer R L, Zeng R J, Giugliano V, Blackall L L. Challenges for simultaneous nitrification, denitrifation, and phosphorus removal in microbial aggregates: mass transfer limitation and nitrous oxide production. FEMS Microbiology Ecology. 52(2005)329-338.

[11]Robert J,Mino T, OnukiM. The microbiology of biological phosphorus removal in activated sludge systems. FEMS. Microbiology Reviews. 27(2003)99-127.

[12] Hu J Y, Ong S L, Ng W J, Lu F, Fan X J. A new method for characterizing denitrifying phosphorus removal bacteria by using three different types of electron acceptors. Water Research. 37(2003)3463-3471.

[13]PENG Yongzhen, HOU Hongxun,WANG Shuying, CUI Youwei, Zhiguo Yuan. Nitrogen and phosphorus removal in pilot-scale anaerobic-anoxic oxidation ditch system. Journal of Environmental Sciences. 20(2008) 398-403 
[14]Zhimin Fu, Fenglin Yang, Yingyu An, Yuan Xue. Simultaneous nitrification and denitrification coupled with phosphorus removal in an modified anoxic/oxic-membrane bioreactor (A/O-MBR). Biochemical Engineering Journal. 43(2009)191-196

[15]Lemaire R, Meyer R, Taske A, Crocetti G R, Keller J, Yuan Z. Identifying causes for $\mathrm{N}_{2} \mathrm{O}$ accumulation in a labscale sequencing batch reactor performing simultaneous nitrification, denitrification and phosphorus removal. Journal of Biotechnology. 122(2006)62-72.

[16] M Tiranuntakul, V Jegatheesana, P A Schneider H L Fracchia.. Performance of an oxidation ditch retrofitted with a membrane bioreactor during the start-up. Desalination. 183(2005)417-424.

[17] X D Hao, H J Doddema, J W van Groenestijn. Conditions and mechanisms affecting simultaneous nitrification and denitrification in a Pasveer oxidation ditch. Bioresource Technology. 59(1997)207-215.

[18]Y Z Peng, X L Wang, W M Wu, J Li, J Fan. Optimisation of anaerobic/anoxic/oxic process to improve performance and reduce operating costs. J.Chem. Technol. Biotechnol. 81 (2006)13911397.

[19]X L Wang, Y Z Peng, S Y Wang, J Fan, X M Cao. Influent of wastewater composition on nitrogen and phosphorus removal and process control in $\mathrm{A}^{2} \mathrm{O}$ process. Bioprocess Biosystem Eng, 28(2006)397-404.

[20]Y Ma, Y Z Peng, X L Wang, S Y Wang, Nutrient removal performance of an anaerobicanoxicaerobic process as a function of influent C/P ratio. J. Chem. Technol. Biotechnol., 80(2005)11181124.

[21]Shuai Yang, Fenglin Yang, Zhimin Fu, Tao Wang, Ruibo Lei. Simultaneous nitrogen and phosphorus removal by a novel sequencing batch moving bed membrane bioreactor for wastewater treatment. Journal of Hazardous Materials. 175(2010)551-557.

[22]Limei Yuan, Chuanyi Zhang, Yanqiu Zhang, Yi Ding, Danli Xi. Biological nutrient removal using an alternating of anoxic and anaerobic membrane bioreactor (AAAM) process. Desalination. 221(2008)566-575. 